\title{
PENGARUH KOMPENSASI DAN PELATIHAN KERJA TERHADAP KINERJA KARYAWAN PADA PT DIPO INTERNASIONAL PAHALA OTOMOTIF DENGAN KEPUASAN KERJA SEBAGAI VARIABEL INTERVENING
}

\author{
Jam'an Amadi \\ Universitas IBBI \\ Email: jaman.unibbi@gmail.com
}

\begin{abstract}
ABSTRAK
Tujuan penelitian ini adalah untuk mengetahui pengaruh kompensasi dan pelatihan kerja terhadap kinerja karyawan pada PT Dipo Internasional Pahala Otomotif dengan kepuasan kerja sebagai variabel intervening. Metode yang digunakan dalam penelitian ini adalah dengan metode deskriptif, jenis penelitian ini adalah data kuantitatif, data primer yang diperoleh melalui kuesioner. Populasi pada penelitian ini adalah seluruh karyawan pada perusahaan sebanyak 97 karyawan. Teknik pengambilan sampel yang digunakan adalah sampel jenuh dimana seluruh populasi dijadikan sebagai sampel penelitian. Teknik analisis yang digunakan adalah analisis linier berganda. Hasil pengujian yang menunjukkan bahwa secara parsial maupun simultan variabel kompensasi dan pelatihan kerja berpengaruh positif dan signifikan terhadap kinerja karyawan dengan kepuasan kerja sebagai variabel intervening
\end{abstract}

Kata Kunci : Kompensasi, Pelatihan Kerja, Kepuasan Kerja, Kinerja

\section{Pendahuluan}

Di era persaingan global yang ketat ini, kesejahteraan karyawan merupakan hal mutlak yang menjadi tanggung jawab perusahaan. Faktor utama dalam keberhasilan organisasi itu sendiri yaitu karyawan. Ketika hak dan kewajiban karyawan terpenuhi, kualitas kinerja karyawan akan meningkat sehingga visi dan misi perusahaan dapat tercapai secara efektif dan efisien. Menurut Wibowo (2017:70), Kinerja dapat dipandang sebagai proses maupun hasil pekerjaan dimana suatu proses tentang bagaimana pekerjaan berlangsung untuk mencapai hasil kerja. Untuk itu sudah sepantasnya perusahaan memperhatikan faktor-faktor yang mempengaruhi kinerja para karyawan karena sumber daya manusia yang berkualitas tentu akan memberikan dampak positif setiap perusahaan, salah satunya di dunia perbankan.

Faktor yang mempengaruhi kinerja pada dasarnya adalah kemauan kerja karyawan atas kepuasan kerja, Kepuasan kerja adalah sikap emosional yang menyenangkan dan mencintai pekerjaannya. Sikap ini dicerminkan oleh moral kerja, kedisiplinan dan prestasi kerja. Kepuasan kerja dinikmati dalam pekerjaan, luar pekerjaan dan kombinasi dalam dan luar pekerjaan. Secara umum pengukuran kepuasan kerja dalam karyawan dapat terlihat dari kedisiplinan karyawan dalam melaksanakan pekerjaannya dan moral kerja yang ditunjukkan kepada sesamarekan kerja ataupun pimpinan serta tingkat turnover perusahaan yang relatif kecil agar tujuan perusahaan dapat tercapai efektif dan efisien.

Salah satu faktor yang mempengaruhi kinerja karyawan adalah sistem kompensasi, pada dasarnya untuk mencapai kepuasan kerja dalam diri karyawan yang diinginkan oleh setiap perusahaan, selayaknya perusahaan harus memperhatikan penerapan kompensasi yang diberikan. faktor lain yang mempengaruhi kinerja adalah kemampuan, faktor kemampuan ini merupakan hasil dari pelatihan. Pelatihan merupakan serangkaian aktivitas individu dalam meningkatkan keahlian dan pengetahuan secara sistematis sehingga mampu memiliki kinerja yang profesional di bidangnya. Dengan pelatihan yang baik, kepuasan kerja karyawan dapat meningkat. Oleh sebab itu materi pelatihan yang diberikan harus dapat menambah wawasan, pengetahuan dan juga pengalaman karyawan sehingga karyawan dapat tetap proaktif untuk belajar. Metode pelatihan yang diberikan dan instruktur yang digunakan tidak membosankan bagi karyawan sehingga tidak adanya kejenuhan karyawan dalam menjalankan pelatihan dan terdapat kepuasan tersendiri.

PT Dipo Internasional Pahala Otomotif 
adalah sebuah dealer resmi yang menjalankan 3S yaitu Sales, Service dan Sparepart. Sebagai dealer 3S, DIPO memiliki layanan penjualan yang lengkap dan nyaman disertai fasilitas test drive untuk calon konsumennya. Dealer ini dilengkapi berbagai produk yang dapat ditawarkan.

Berdasarkan latar belakang masalah diatas yang peneliti terima dari hasil wawancara dengan beberapa karyawan yang bekerjan disana membuat peneliti tertarik untuk melakukan penelitian dengan judul "Pengaruh Kompensasi dan Pelatihan Terhadap Kinerja Karyawan Pada PT Dipo Internasional Pahala Otomotif Dengan Kepuasan Kerja Sebagai Variabel Intervening."

\section{Kajian Teoritis Kompensasi}

Hasibuan (2016) kompensasi adalah semua pendapatan yang berbentuk uang, barang langsung atau tidak langsung yang diterima karyawan sebagai imbalan atas jasa yang diberikan kepada perusahaan. Sedangkan Sinambela (2017) menjelaskan kompensasi merupakan salah satu alasan dan motivasi utama mengapa karyawan bekerja. Karyawan menggunakan seluruh pengetahuan, keterampilan, tenaga, waktu, serta komitmennya bukan semata-mata ingin membaktikan atau mengabdikan diri kepada perusahaan, melainkan tujuan lain yang ingin diraihnya yaitu mengharapkan imbalan atau balas jasa atas kinerja dan produktivitas kerja yang telah dihasilkan oleh karyawan.

$$
\text { Wibowo (2017) kompensasi }
$$

merupakan kontra prestasi terhadap penggunaan tenaga atau jasa yang telah diberikan oleh tenaga kerja dan sebagai paket yang ditawarkan organisasi kepada pekerja sebagai imbalan atas penggunaan tenaga kerjanya. Sunyoto (2015) kompensasi didefinisikan sebagai sesuatu yang diterima oleh karyawan sebagai balas jasa untuk kerjanya. Namun sebelum kompensasi diberikan, terlebih dahulu dilakukan proses kompensasi yaitu suatu jaringan berbagai proses untuk memberikan balas jasa kepada karyawan untuk pelaksanaan pekerjaan dan untuk memotivasi karyawan agar mencapai tingkat prestasi yang diinginkan

Kkompensasi merupakan total dari semua hadiah yang diberikan organisasi kepada pegawai sebagai imbalan atas jasa mereka dan menjadi hal yang menarik, mempertahankan, dan memotivasi pegawai agar memberikan tenaga dan pikiran yang terbaik bagi perusahaan.

\section{Pelatihan}

Widodo (2015) pPelatihan merupakan serangkaian aktivitas individu dalam meningkatkan keahlian dan pengetahuan karyawan secara sistematis sehingga karyawan mampu memiliki kinerja yang profesional di bidangnya. Pelatihan adalah proses pembelajaran yang memungkinkan pegawai melaksanakan pekerjaan yang sekarang sesuai dengan standar. Sedangkan Rachmawati (2017) pelatihan merupakan wadah lingkungan bagi karyawan, di mana mereka memperoleh atau mempelajari sikap, kemampuan, keahlian, pengetahuan, dan perilaku spesifik yang berkaitan dengan pekerjaan".

Rivai dan Sagala (2016) menjelaskan pelatihan adalah proses secara sistematis mengubah tingkah laku pegawai untuk mencapai tujuan organisasi. Pelatihan berkaitan dengan keahlian dan kemampuan pegawai untuk melaksanakan pekerjaan saat ini dan Sedarmayanti (2015) pelatihan adalah sarana yang ditunjukkan sebagai upaya untuk lebih mengaktifkan kerja para anggota-anggota organisasi yang kurang aktif sebelumnya, mengurangi dampak negatif yang dikarenakan kurangnya pendidikan, pengalaman yang terbatas atau kurangnya kepercayaan diri dari anggota atau kelompok anggota tertentu.

Berdasarkan pendapat para ahli di atas maka dapat disimpulkan yang dimaksud pelatihan dalam penelitian ini adalah sarana yang ditunjukkan sebagai upaya untuk lebih mengaktifkan kerja para anggota-anggota organisasi yang kurang aktif sebelumnya, mengurangi dampak negatif yang dikarenakan kurangnya pendidikan, pengalaman yang terbatas atau kurangnya kepercayaan diri dari anggota atau kelompok anggota tertentu.

\section{Kepuasan Kerja}

Hasibuan (2016) kepuasan kerja adalah sikap emosional yang menyenangkan dan mencintai pekerjaannya. Sikap ini dicerminkan oleh moral kerja, kedisiplinan, dan prestasi kerja. Kepuasan kerja dinikmati dalam pekerjaan, luar pekerjaan dan kombinasi dalam dan luar pekerjaan. Siagian (2015) menjelaskan kepuasan mempunyai konotasi yang beraneka ragam, namun demikian tetap relevan untuk mengatakan bahwa kepuasan kerja merupakan suatu cara pandang seseorang baik yang bersifat positif maupun negatif tentang pekerjaannya.

Badeni (2017) kepuasan kerja karyawan merupakan salah satu elemen yang cukup penting dalam organisasi. Hal ini disebabkan kepuasan kerja personel organisasi 
dapat mempengaruhi perilaku kerja seperti malas, rajin, produktif, dan lain-lain atau mempunyai hubungan dengan beberapa jenis perilaku yang sangat penting dalam organisasi.

Berdasarkan pendapat para ahli diatas, dapat peneliti simpulkan bahwa kepuasan kerja merupakan suatu sikap emosional yang menyenangkan dan mencintai pekerjaannya dan juga salah satu elemen yang cukup penting dalam organisasi yang menjadi cara pandang seseorang baik bersifat negatif maupun positif dalam pekerjaannya.

\section{Kinerja}

Bangun (2016) kinerja atau performance merupakan proses untuk mengidentifikasi, mengukur dan mengevaluasi kinerja karyawan dalam perusahaan. Sedangkan Wibowo (2017) kinerja dapat dipandang sebagai proses maupun hasil pekerjaan. Kinerja merupakan suatu proses tentang bagaimana pekerjaan berlangsung untuk mencapai hasil kerja. Namun hasil pekerjaan tersebut juga menunjukkan kinerja. Kinerja juga merupakan sebuah hasil pekerjaan yang mempunyai hubungan kuat dengan tujuan strategis organisasi, kepuasan konsumen, dan memberikan kontribusi pada ekonomi”.

Darmawan (2018) mendenfinikan kegiatan penilaian kinerja difokuskan pada usaha mengungkapkan kekurangan dalam bekerja untuk diperbaiki dan kelebihan bekerja untuk dikembangkan, agar setiap karyawan mengetahui tingkat efisiensi dan efektivitas kontribusinya untuk melaksanakan pekerjaannya guna mencapai tujuan organisasi non-profit yang memperkerjakannya. Sementara Rivai dkk (2015) "Penilaian kinerja dapat digunakan untuk menekan perilaku yang tidak semestinya diinginkan, melalui umpan balik hasil kinerja pada waktunya serta pemberian penghargaan, baik yang bersifat intrinsik maupun ekstrinsik".

Sinambela (2017) mendefinisikan kinerja adalah kemampuan karyawan dalam melakukan sesuatu keahlian tertentu. Penggunaan kata kinerja sendiri terkadang di sama artikan dengan prestasi kerja, efektivitas kerja, hasil kerja, pencapaian tujuan, produktivitas kerja, dan berbagai istilah lainnya. Kinerja karyawan sangatlah penting sebab dengan kinerja inilah akan diketahui seberapa jauh kemampuan mereka dalam melaksanakan tugas yang dibebankan kepada setiap karyawan. Untuk itulah diperlukan penentuan kriteria yang jelas dan terukur serta ditetapkan secara bersama-sama untuk dijadikan sebagai acuan.
Berdasarkan pendapat para ahli di atas, peneliti dapat menyimpulkan bahwa kinerja adalah hasil atau tingkat keberhasilan karyawan dalam melaksanakan tugas yang dibebankan untuk mencapai tujuan organisasi.

\section{Kerangka Penelitian}

Adapun kerangka penelitian ini adalah sebagai berikut;

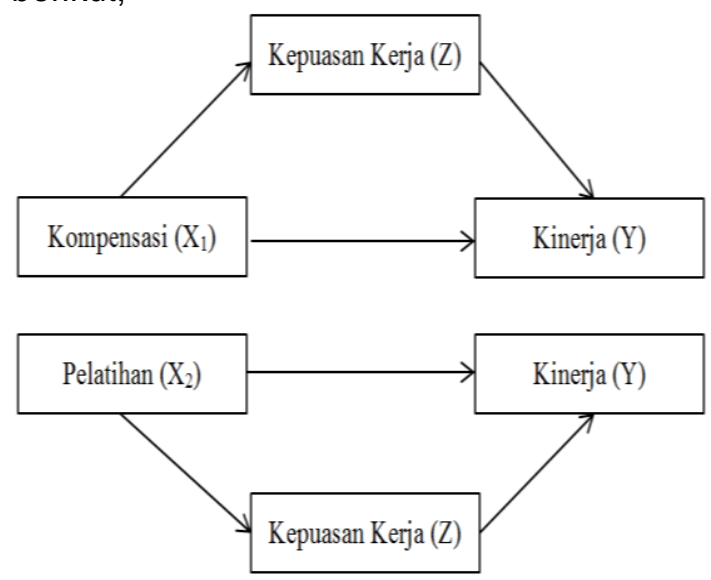

Metodelogi

Data yang digunakan dalam penelitian ini adalah data primer seluruh karyawan PT Dipo Internasional Pahala Otomotif yang berjumlah 97 karyawan. Untuk menguji pengaruh variabel intervening maka digunakan metode analisis jalur. Analisis jalur merupakan perluasan analisis regresi linier berganda atau analisis jalur adalah penggunaan analisis regresi untuk menaksir hubungan kausualitas antar variabel yang telah ditetapkan sebelumnya. Adapun persamaan sebagai berikut:

$$
\begin{gathered}
Y=a+b_{1} X_{1}+b_{2} X_{2}+e \\
Y=a+Z+b_{1} X_{1}+b_{2} X_{2}+e
\end{gathered}
$$

\begin{tabular}{|c|c|c|}
\hline Keterangan : & $\begin{array}{l}Y \\
Z \\
X_{1} \\
X_{2} \\
a \\
b_{1}, b_{2} \\
e\end{array}$ & $\begin{array}{l}=\text { Kinerja } \\
=\text { Kepuasan Kerja } \\
=\text { Kompensasi } \\
=\text { Pelatihan } \\
=\text { Konstanta } \\
=\text { Koefisien regresi } \\
=\text { error }\end{array}$ \\
\hline
\end{tabular}

\section{Hasil dan Pembahasan Uji Validitas}

Hasil uji validitas dapat dilihat pada tabel dibawah dengan ketentuan jika $r_{\text {hitung }}>r_{\text {tabel }}$ $(0,361)$ atau nilai sig $<0,05$ maka item pernyataan dianggap valid: 
Hasil Uji Validitas Instrumen

\begin{tabular}{|c|c|c|c|c|}
\hline \multicolumn{2}{|c|}{ Variabel Penelitian } & $\mathbf{r}_{\text {hitung }}$ & $\mathbf{r}_{\text {tabel }}$ & Keterangan \\
\hline \multirow{4}{*}{$\begin{array}{c}\text { Kompensasi } \\
\left(\mathrm{X}_{1}\right)\end{array}$} & $\begin{array}{c}\text { Pernyataan } \\
1\end{array}$ & 0,776 & 0,361 & Valid \\
\hline & $\begin{array}{c}\text { Pernyataan } \\
2\end{array}$ & 0,797 & 0,361 & Valid \\
\hline & $\begin{array}{c}\text { Pernyataan } \\
3\end{array}$ & 0,874 & 0,361 & Valid \\
\hline & $\begin{array}{c}\text { Pernyataan } \\
4\end{array}$ & 0,795 & 0,361 & Valid \\
\hline \multirow{4}{*}{$\begin{array}{c}\text { Pelatihan } \\
\text { kerja } \\
\left(\mathrm{X}_{2}\right)\end{array}$} & $\begin{array}{c}\text { Pernyataan } \\
1\end{array}$ & 0,778 & 0,361 & Valid \\
\hline & $\begin{array}{c}\text { Pernyataan } \\
2\end{array}$ & 0,781 & 0,361 & Valid \\
\hline & $\begin{array}{c}\text { Pernyataan } \\
3\end{array}$ & 0,781 & 0,361 & Valid \\
\hline & $\begin{array}{c}\text { Pernyataan } \\
4\end{array}$ & 0,612 & 0,361 & Valid \\
\hline \multirow{6}{*}{$\begin{array}{l}\text { Kepuasan } \\
\text { kerja } \\
(\mathrm{Z})\end{array}$} & $\begin{array}{c}\text { Pernyataan } \\
1\end{array}$ & 0,878 & 0,361 & Valid \\
\hline & $\begin{array}{c}\text { Pernyataan } \\
2 \\
\end{array}$ & 0,863 & 0,361 & Valid \\
\hline & $\begin{array}{c}\text { Pernyataan } \\
3 \\
\end{array}$ & 0,669 & 0,361 & Valid \\
\hline & $\begin{array}{c}\text { Pernyataan } \\
4\end{array}$ & 0,731 & 0,361 & Valid \\
\hline & $\begin{array}{c}\text { Pernyataan } \\
5\end{array}$ & 0,729 & 0,361 & Valid \\
\hline & $\begin{array}{c}\text { Pernyataan } \\
6 \\
\end{array}$ & 0,809 & 0,361 & Valid \\
\hline \multirow{5}{*}{$\begin{array}{c}\text { Kinerja } \\
\text { karyawan } \\
(\mathrm{Y})\end{array}$} & $\begin{array}{c}\text { Pernyataan } \\
1\end{array}$ & 0,838 & 0,361 & Valid \\
\hline & $\begin{array}{c}\text { Pernyataan } \\
2 \\
\end{array}$ & 0,702 & 0,361 & Valid \\
\hline & $\begin{array}{c}\text { Pernyataan } \\
3 \\
\end{array}$ & 0,805 & 0,361 & Valid \\
\hline & $\begin{array}{c}\text { Pernyataan } \\
4\end{array}$ & 0,801 & 0,361 & Valid \\
\hline & $\begin{array}{c}\text { Pernyataan } \\
5\end{array}$ & 0,735 & 0,361 & Valid \\
\hline
\end{tabular}

Sumber : Hasil Penelitian, 2020 (Data Diolah)

Berdasarkan tabel diatas dapat dilihat seluruh $r_{\text {hitung }}$ pernyataan memiliki nilai lebih besar dari $r_{\text {tabel }}$ sehingga diperoleh hasil bahwa semua pernyataan kuesioner adalah valid dan layak digunakan dengan nilai tertinggi.

\section{Uji Reliabilitas}

Cara pengukuran reliabilitas adalah seluruh item pernyataan yang telah valid dimasukan dan diukur koefisien Cronbach's Alpha. Jika nilai yang diperoleh lebih besar dari 0,6 maka kuesioner tersebut reliabel.

Tabel 2 Uji Reliabilitas Instrumen

\begin{tabular}{|c|c|c|}
\hline Variabel & $\begin{array}{c}\text { Cronbach's } \\
\text { Alpha }\end{array}$ & $\begin{array}{l}\mathrm{N} \text { of } \\
\text { Items }\end{array}$ \\
\hline Kompensasi $\left(\mathrm{X}_{1}\right)$ & 0,820 & 4 \\
\hline Pelatihan kerja $\left(\mathrm{X}_{2}\right)$ & 0,715 & 4 \\
\hline Kepuasan kerja (Z) & 0,873 & 6 \\
\hline Kinerja karyawan (Y) & 0,829 & 5 \\
\hline
\end{tabular}

Berdasarkan tabel diatas dapat dilihat instrumen dikatakan reliable karena nilai koefisien alpha cronbach lebih besar dari 0,6 ( $\alpha$ $\geq 0,6$ ) sehingga jawaban yang diberikan responden dapat dipercaya atau dapat diandalkan (reliable). Dengan demikian maka instrumen yang digunakan dalam penelitian ini handal

\section{Hasil Analisis}

Hasil pengujian analisis regresi linier berganda dapat dilihat pada kedua tabel persamaan dibawah berikut ini :

Tabel 3 Analisis Regresi Linier Berganda Persamaan I

\begin{tabular}{|ll|r|r|r|}
\hline \multicolumn{1}{|l|}{ Model } & \multicolumn{2}{|c|}{$\begin{array}{c}\text { Unstandardized } \\
\text { Coefficients }\end{array}$} & $\begin{array}{c}\text { Standardized } \\
\text { Coefficients }\end{array}$ \\
\cline { 3 - 5 } & \multicolumn{1}{|c|}{ B } & Std. Error & \multicolumn{1}{c|}{ Beta } \\
\hline 1 & (Constant) & 10,282 & 2,150 & \\
& Kompensasi &, 441 &, 129 &, 310 \\
& Pelatihan &, 384 &, 099 &, 351 \\
\hline
\end{tabular}

a. Dependent Variable: Kepuasan Kerja

Sumber : Hasil Penelitian, 2020 (Data Diolah)

Pada tabel diatas, diketahui pada Unstandardized Coefficeints bagian B diperoleh persamaan regresi linier berganda pertama yaitu dengan rumus berikut :

$$
\begin{gathered}
Z=\alpha+b_{1} X_{1}+b_{2} X_{2}+e \\
Z=10,282+0,441 X_{1}+0,384 X_{2}+e
\end{gathered}
$$

Konstanta $(\alpha)=10,282$ menunjukkan nilai konstanta, jika nilai variabel kompensasi dan pelatihan kerja bernilai 0 maka kepuasan kerja karyawan adalah tetap sebesar 10,282. Koefisien $b_{1}=0,441$ menunjukkan bahwa variabel kompensasi berpengaruh positif terhadap kepuasan kerja karyawan sebesar 0,441 . Artinya setiap peningkatan aspek kompensasi sebesar 1 satuan, maka kepuasan kerja karyawan akan meningkat sebesar 0,441.

Koefisien $b_{2}=0,384$ menunjukkan bahwa variabel pelatihan kerja berpengaruh positif terhadap kepuasan kerja karyawan sebesar 0,384. Artinya setiap peningkatan pelatihan kerja sebesar 1 satuan, maka kepuasan kerja karyawan akan meningkat sebesar 0,384.

Tabel 4 Analisis Regresi Linier Berganda Persamaan 2

\begin{tabular}{|l|r|r|r|}
\hline Model & \multicolumn{2}{|c|}{$\begin{array}{c}\text { Unstandardized } \\
\text { Coefficients }\end{array}$} & $\begin{array}{c}\text { Standardized } \\
\text { Coefficients }\end{array}$ \\
\cline { 2 - 4 } & \multicolumn{1}{|c|}{ B } & Std. Error & \multicolumn{1}{c|}{ Beta } \\
\hline 2 (Constant) & 5,291 & 1,929 &, 251 \\
Kompensasi &, 300 &, 110 &, 288 \\
Pelatihan &, 265 &, 086 &, 231 \\
Kepuasan &, 194 &, 083 &, \\
$\quad$ Kerja & & & \\
\hline
\end{tabular}

a. Dependent Variable: Kinerja Kaaryawan

Sumber : Hasil Penelitian, 2020 (Data Diolah)

Pada Unstandardized Coefficeints bagian $B$ diperoleh persamaan regresi linier berganda pertama yaitu dengan rumus berikut : 


$$
\begin{gathered}
Y=\alpha+b_{1} X_{1}+b_{2} X_{2}+Z+e \\
Y=5,291+0,300 X_{1}+0,265 X_{2}+0,194+e
\end{gathered}
$$

Berdasarkan persamaan kedua diatas maka dapat diuraikan dibawah nilai konstanta $(\alpha)=5,291$ menunjukkan nilai konstanta, jika nilai variabel kompensasi, pelatihan kerja dan kepuasan kerja bernilai 0 maka kinerja karyawan adalah tetap sebesar 5,291. Koefisien $b_{1}=0,300$ menunjukkan bahwa variabel kompensasi berpengaruh positif terhadap kinerja karyawan sebesar 0,300. Artinya setiap peningkatan aspek kompensasi sebesar 1 satuan, maka kinerja karyawan akan meningkat sebesar 0,300 .

Koefisien $b_{2}=0,265$ menunjukkan bahwa variabel pelatihan kerja berpengaruh positif terhadap kinerja karyawan sebesar 0,265 . Artinya setiap peningkatan pelatihan kerja sebesar 1 satuan, maka kinerja karyawan akan meningkat sebesar 0,265 . Koefisien $Z=$ 0,194 menunjukkan bahwa variabel kepuasan kerja berpengaruh positif terhadap kinerja karyawan sebesar 0,194. Artinya setiap peningkatan kepuasan kerja sebesar 1 satuan, maka kinerja karyawan akan meningkat sebesar 0,194.

Secara keseluruhan hasil temuan menunjukkan bahwa dalam jangka pendek variabel gini rasio dan jumlah penduduk berpengaruh terhadap kemiskinan, sedangkan dalam jangka panjang tidak berpengaruh terhadap kemiskinan kabupaten/kota di Aceh. . Hal ini dapat dilihat dari aspek kualitas pertumbuhan penduduk yang mana Pertumbuhan penduduk yang berakibat positif apabila pertumbuhannya dapat mendorong pembangunan ekonomi, artinya ketika terjadi peningkatan jumlah penduduk dapat memungkinkan bertambahnya tenaga kerja yang mampu mendorong sektor produksi untuk meningkatkan kegiatan perekonomian.

Kelemahan penelitian ini adalah jumlah tahun lebih kecil dibandingkan dengan jumlah kabupaten/kota. Hal ini terjadi karena banyak daerah hasil pemekaran yang tidak memiliki data. Sehingga digunakan tada tahunan. Data kuartalan juga tidak tersedia terutama untuk data penduduk.

Bagi peneliti selanjutnya jika ingin meneliti dibidang yang sama, disarankan untuk menggunakan variabel penelitian yang lebih banyak, sehingga dapat memberikan hasil penelitian yang lebih baik. variabel lain misalnya: pendidikan, IPM serta memperluas sampel misalnya: quartalan atau data bulanan serta bisa memperpanjang range tahun nya.

\section{Analisis Jalur (Path Analyse) \\ Hasil analisis jalur variabel Kompensasi dapat dilihat gambar dibawah}

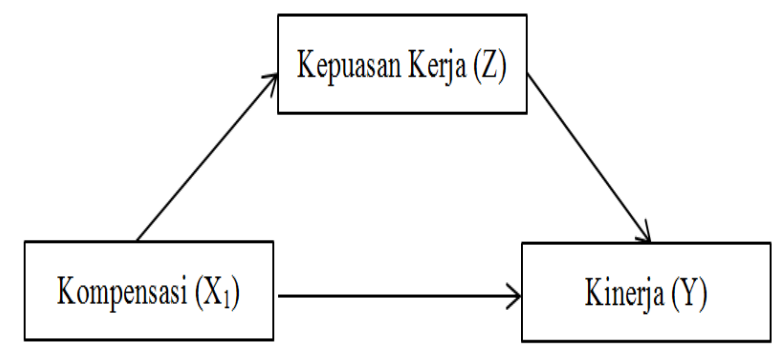

Analisis Jalur $X_{1}$ Terhadap $Y$ Dengan $Z$ sebagai Variabel Intervening

Berdasarkan gambar diatas, dapat dilihat bahwa hasil analisis menunjukkan bahwa kompensasi $\left(X_{1}\right)$ dapat berpengaruh langsung terhadap kinerja karyawan $(\mathrm{Y})$ dan dapat juga berpengaruh tidak langsung melalui kepuasan kerja (Z) sebagai intervening. Besarnya pengaruh langsung adalah 0,300 sedangkan besarnya pengaruh tidak langsung $\mathrm{P} 2 \times \mathrm{P} 3=(0,441 \times 0,194)=0,0856$. Total pengaruh $X_{1}$ (Kompensasi) terhadap $Y=0,300$ $+0,0856=0,3856$.

Hasil analisis jalur variabel Pelatihan kerja dapat dilihat pada gambar dibawah:

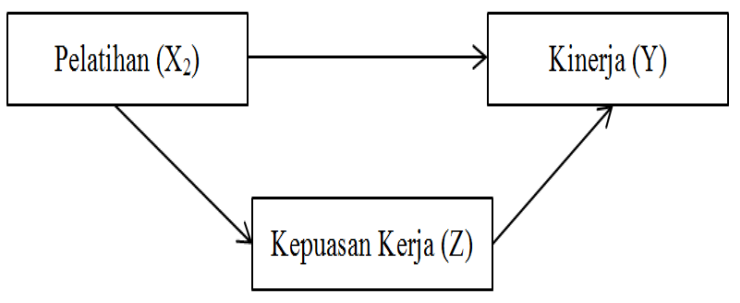

\section{Analisis Jalur $\mathbf{X}_{2}$ Terhadap $Y$ Dengan $Z$ sebagai Variabel Intervening}

Berdasarkan gambar diatas, dapat dilihat bahwa hasil analisis menunjukkan bahwa pelatihan kerja $\left(\mathrm{X}_{2}\right)$ dapat berpengaruh langsung terhadap kinerja karyawan $(\mathrm{Y})$ dan dapat juga berpengaruh tidak langsung melalui kepuasan kerja (Z) sebagai intervening. Besarnya pengaruh langsung adalah 0,265 sedangkan besarnya pengaruh tidak langsung P2 $\times$ P3 $=(0,384 \times 0,194)=0,0745$. Total pengaruh $\mathrm{X}_{2}$ (Pelatihan kerja) terhadap $\mathrm{Y}=$ $0,265+0,0745=0,3395$.

\section{Kesimpulan}

1. Kompensasi secara parsial berpengaruh terhadap kinerja karyawan pada PT Dipo Internasional Pahala Otomotif. 
2. Kompensasi secara parsial berpengaruh terhadap kepuasan kerja karyawan pada PT Dipo Internasional Pahala Otomotif.

3. Kompensasi secara parsial berpengaruh terhadap kinerja karyawan pada PT Dipo Internasional Pahala Otomotif melalui kepuasan kerja.

4. Pelatihan secara parsial berpengaruh terhadap kinerja karyawan pada PT Dipo Internasional Pahala Otomotif.

5. Pelatihan secara parsial berpengaruh terhadap kepuasan kerja karyawan pada PT Dipo Internasional Pahala Otomotif.

6. Pelatihan secara parsial berpengaruh terhadap kinerja karyawan pada PT Dipo Internasional Pahala Otomotif melalui kepuasan kerja.

7. Kompensasi, pelatihan dan kepuasan kerja secara simultan berpengaruh terhadap kinerja karyawan pada PT Dipo Internasional Pahala Otomotif.

\section{Daftar Pustaka}

Badeni. 2017. Kepemimpinan dan Perilaku Organisasi Edisi Ketiga. Bandung : Alfabeta.

Bangun, Wilson. 2016. Manajemen Sumber Daya Manusia. Jakarta : Erlangga

Darma, Prayoga Setia dan Achmad Sani Supriyanto. 2017. The Effect of Compensation and Training to Dinas PU Pasaman Employee Performance With Job Satisfaction as Intervening. Journal of Faculty Economics.

Darmawan, Kuncoro Achmad. 2018. Konsep Penerapan Manajemen Sumber Daya Manusia : Penerapan Teori dan Praktik. Bandung : CV. Alfabeta.

Fakhri, Risha Faiq dan Indi Djastuti. 2015. Pengaruh Kompensasi dan Pelatihan Terhadap Kinerja Karyawan Dengan Kepuasan Kerja Sebagai Variabel Intervening (Studi Pada PT. Audio Sumitomo Technologyy (AST) Indonesia). Jurnal Administrasi Bisnis.

Ghozali, Imam. 2013. Aplikasi Analisis Multivariete Dengan Program IBM SPSS. Semarang : BP Universitas Diponegoro.

Hasibuan, Malayu S.P. 2016. Manajemen Sumber Daya Manusia Edisi Kesembilan Belas. Jakarta : PT. Bumi Aksara.
Herlina, Vivi. 2019. Panduan Praktis Mengolah Data Kuesioner Menggunakan SPSS. Jakarta : PT. Elex Media Komputindo.

Hidayah, Nurul. 2016. Pengaruh Kompensasi Terhadap Kinerja Karyawan Melalui Kepuasan Kerja Sebagai Intervening (Studi Pada Karyawan Bagian Keuangan dan Akuntansi Universitas Negeri Yogyakarta). Jurnal Manajemen Ekonomi Bisnis.

Islam, Md Monirul, Tanvir Mahady Dip \& Md Abdullah Al Hossain. 2017. The Effect of Job Training and Compensation on Employee Performance With Job Satisfaction as Intervening at Hormuud Company Mogadishu. International Journal of Economy Science.

Jaya, I Made Laut Mertha Jaya. 2019. Pengolahan Data Kesehatan Dengan SPSS. Penerbit Thema Publishing, Yogyakarta.

Mangkunegara, Anwar Prabu. 2016. Sumber Daya Manusia Perusahaan Cetakan Kedua Belas. Bandung : Remaja Rosdakarya.

Priyatno, Dwi. 2018. SPSS Panduan Mudah Olah Data Bagi Mahasiswa \& Umum. Yogyakarta : CV. Andi Offset.

Rachmawati, Irdianti. 2017. Manajemen Sumber Daya Manusia Dalam Pendekatan Keorganisasian. Jakarta : PT. Raja Grafindo Persada.

Rivai, Mohammad dan Sagala Indriawanti. 2016. Kepemimpinan dan Perilaku Organisasi. Jakarta : UB Press.

Rivai, Azwar Samsudin, Jonathan Sarwono dan Bedjo Silalahi. 2015. Pengaruh Penilaian Kinerja Dalam Menghasilkan Hasil Kerja Karyawan Yang Optimal Dalam Kegiatan Berorganisasi. Jurnal Fakultas Ekonomi Universitas Yogyakarta.

Salinding, Nuartansi. 2017. Pengaruh Pelatihan Karyawan dan Pengawasan Terhadap Peningkatan Kinerja Karyawan (Studi Kasus Pada Karyawan PT. Nuansa Sumber Indahtani). Jurnal Fakultas Ekonomi Universitas Yogyakarta. 
Sedarmayanti. 2017. Manajemen Sumber Daya Manusia, Reformasi Birokrasi dan Manajemen Pegawai Negeri Sipil Edisi Kesembilan. Jakarta : PT. Erlangga.

Siagian, Sondang P. 2015. Manajemen Sumber Daya Manusia. Jakarta : PT. Bumi Aksara.

Simamora, Hadari Ashar. 2018. Manajemen Sumber Daya Manusia Edisi Revisi. Jakarta : Elex Media Komputindo.

Sinambela, Lijan Poltak. 2017, Manajemen Sumber Daya Manusia (Membangun Tim Kerja Yang Solid Untuk Meningkatkan Kinerja). Jakarta : PT. Bumi Aksara.

Sunyoto, Danang. 2012. Manajemen Sumber Daya Manusia Edisi Kedua. Yogyakarta : CAPS.

2015. Manajemen Sumber Daya Manusia Edisi Revisi. Yogyakarta : CAPS.

Sutrisno, Sonny. 2016. Manajemen Sumber Daya Manusia Untuk Perusahaan. Bandung : Alfabeta.

Wibowo, Hutagaol. 2017. Manajemen Pengelolaan Sumber Daya Manusia. Yogyakarta : CAPS

Widodo, Hendrik. 2015. Perilaku Keorganisasian. Yogyakarta : BPFE.

Yatnasari, Astri. 2018. Pengaruh Pelatihan dan Kompensasi Terhadap Kinerja Guru SMK Swasta di Gadingrejo Melalui Kepuasan Kerja Sebagai Variabel Intervening. Jurnal Fakultas Ekonomi Universitas Prima Indonesia. 